\title{
Article \\ Clinically Relevant Concentrations of Polymyxin B and Meropenem Synergistically Kill Multidrug-Resistant Pseudomonas aeruginosa and Minimize Biofilm Formation
}

\author{
Hasini Wickremasinghe ${ }^{1, *(\mathbb{D}, \text { Heidi H. Yu }}{ }^{1}$, Mohammad A. K. Azad ${ }^{1}$, Jinxin Zhao ${ }^{1} \mathbb{(}$, Phillip J. Bergen ${ }^{1}(\mathbb{D}$, \\ Tony Velkov ${ }^{2}{ }^{\circ}$, Qi Tony Zhou ${ }^{3}$, Yan Zhu ${ }^{1}\left(\mathbb{D}\right.$ and Jian $\mathrm{Li}^{1}$ \\ 1 Infection and Immunity Program, Department of Microbiology, Biomedicine Discovery Institute, \\ Monash University, Clayton, VIC 3800, Australia; heidi.yu@monash.edu (H.H.Y.); \\ mohammad.azad@monash.edu (M.A.K.A.); jinxin.zhao@monash.edu (J.Z.); \\ phillip.bergen@monash.edu (P.J.B.); yan.zhu@monash.edu (Y.Z.); jian.li@monash.edu (J.L.) \\ 2 Department of Pharmacology and Therapeutics, School of Biomedical Sciences, Faculty of Medicine, \\ Dentistry and Health Sciences, The University of Melbourne, Parkville, VIC 3053, Australia; \\ tony.velkov@unimelb.edu.au \\ 3 Department of Industrial and Physical Pharmacy, Purdue University, West Lafayette, IN 1047907, USA; \\ tonyzhou@purdue.edu \\ * Correspondence: hasini.wickremasinghe@monash.edu; Tel.: +61-3-9903-9251; Fax: +61-3-9905-6540
}

Citation: Wickremasinghe, H.; Yu, H.H.; Azad, M.A.K.; Zhao, J.; Bergen, P.J.; Velkov, T.; Zhou, Q.T.; Zhu, Y.; Li, J. Clinically Relevant Concentrations of Polymyxin B and Meropenem Synergistically Kill Multidrug-

Resistant Pseudomonas aeruginosa and Minimize Biofilm Formation.

Antibiotics 2021, 10, 405.

https://doi.org/10.3390/

antibiotics10040405

Academic Editor: Giovanna Batoni

Received: 15 March 2021

Accepted: 2 April 2021

Published: 8 April 2021

Publisher's Note: MDPI stays neutral with regard to jurisdictional claims in published maps and institutional affiliations.

Copyright: (C) 2021 by the authors Licensee MDPI, Basel, Switzerland. This article is an open access article distributed under the terms and conditions of the Creative Commons Attribution (CC BY) license (https:// creativecommons.org/licenses/by/ $4.0 /)$.

\begin{abstract}
The emergence of antibiotic resistance has severely impaired the treatment of chronic respiratory infections caused by multidrug-resistant (MDR) Pseudomonas aeruginosa. Since the reintroduction of polymyxins as a last-line therapy against MDR Gram-negative bacteria, resistance to its monotherapy and recurrent infections continue to be reported and synergistic antibiotic combinations have been investigated. In this study, comprehensive in vitro microbiological evaluations including synergy panel screening, population analysis profiling, time-kill kinetics, anti-biofilm formation and membrane damage analysis studies were conducted to evaluate the combination of polymyxin B and meropenem against biofilm-producing, polymyxin-resistant MDR P. aeruginosa. Two phylogenetically

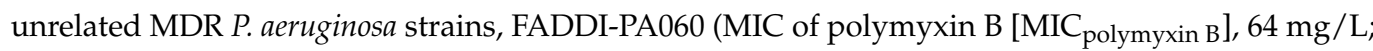
$\mathrm{MIC}_{\text {meropenem, }} 64 \mathrm{mg} / \mathrm{L}$ ) and FADDI-PA107 ( $\mathrm{MIC}_{\text {polymyxin B }}, 32 \mathrm{mg} / \mathrm{L} ; \mathrm{MIC}_{\text {meropenem, }} 4 \mathrm{mg} / \mathrm{L}$ ) were investigated. Genome sequencing identified 57 (FADDI-PA060) and 50 (FADDI-PA107) genes predicted to confer resistance to a variety of antimicrobials, as well as multiple virulence factors in each strain. The presence of resistance genes to a particular antibiotic class generally aligned with MIC results. For both strains, all monotherapies of polymyxin B failed with substantial regrowth and biofilm formation. The combination of polymyxin B $(16 \mathrm{mg} / \mathrm{L}) /$ meropenem $(16 \mathrm{mg} / \mathrm{L})$ was most effective, enhancing initial bacterial killing of FADDI-PA060 by $\sim 3 \log _{10} \mathrm{CFU} / \mathrm{mL}$, followed by a prolonged inhibition of regrowth for up to $24 \mathrm{~h}$ with a significant reduction in biofilm formation $\left({ }^{*} p<0.05\right)$. Membrane integrity studies revealed a substantial increase in membrane depolarization and membrane permeability in the surviving cells. Against FADDI-PA107, planktonic and biofilm bacteria were completely eradicated. In summary, the combination of polymyxin B and meropenem demonstrated synergistic bacterial killing while reinstating the efficacy of two previously ineffective antibiotics against difficult-to-treat polymyxin-resistant MDR P. aeruginosa.
\end{abstract}

Keywords: polymyxin; meropenem; combination therapy; multidrug resistance; Pseudomonas aeruginosa; synergy; biofilm

\section{Introduction}

Infections caused by multidrug-resistant (MDR) Pseudomonas aeruginosa present a serious challenge in clinical practice. This particularly troublesome opportunistic pathogen is notoriously difficult to treat, given its intrinsic resistance to many antibiotics and high 
propensity to develop resistance to all currently available antipseudomonals with monotherapy [1]. In the United States alone, over 32,000 cases of MDR P. aeruginosa were detected in 2017, resulting in 2700 deaths [2]. Indeed, the World Health Organization (WHO) designated carbapenem-resistant $P$. aeruginosa a Priority 1 (Critical) organism urgently requiring novel treatment options [3]. Unfortunately, the drug development pipeline is struggling to match the demand for new antibiotics, including those active against $P$. aeruginosa [4,5]. Consequently, alternative treatment strategies to combat this MDR pathogen, including the improved use of currently available antibiotics, are urgently required.

The emergence of MDR Gram-negative organisms to more recently introduced antibiotics has forced clinicians to re-examine 'old' antibiotics such as the polymyxins [6]. The polymyxins are a multi-component class of non-ribosomal, poly-cationic lipopeptides, and only polymyxin B and E (colistin) are clinically available [7]. Polymyxin B and colistin differ by a single amino acid and have virtually identical potencies and spectrums of activity [7]. This class of antibiotics was once abandoned due to significant toxicity concerns, primarily nephrotoxicity which may occur in up to $60 \%$ of patients receiving intravenous polymyxin therapy [8]. However, given the polymyxins retain significant in vitro activity against many Gram-negative MDR bacteria, including P. aeruginosa $[9,10]$, their use has steadily increased over the last two decades. In many cases, they are the only therapeutic option available to treat infections caused by these MDR pathogens [11].

As is inevitable with any antibiotic, increased polymyxin use has resulted in the emergence of polymyxin resistance in patients, which is beginning to spread worldwide, threatening the utility of this increasingly important last-line therapeutic option [12]. The potential for the rapid emergence of polymyxin resistance even with supra-clinical concentrations has been well demonstrated in pre-clinical studies, including against $P$. aeruginosa [13]. To combat this, polymyxin combination therapy has been proposed as one way to increase antimicrobial activity and reduce the development of resistance [14]. Consequently, polymyxin-based combinations are increasingly used clinically to treat infections caused by MDR Gram-negative organisms, despite a lack of evidence-based treatment guidelines. In such combinations, polymyxins are administered either intravenously and/or, for lung infections, via inhalation $[15,16]$. Therefore, the current study sought to identify an effective, clinically translatable polymyxin B-based combination therapy against biofilm-producing, polymyxin-resistant MDR $P$. aeruginosa. Clinically relevant concentrations of each drug alone and in combination were used to examine bacterial killing of planktonic bacteria, inhibition of biofilm formation, as well as sub-population modulations of the proposed combination via membrane integrity studies.

\section{Results}

2.1. Genome Sequencing, Resistance Genes and Virulence Factors

Genome sequencing yielded approximately 7.6 million reads per sample, equivalent to $2.3 \mathrm{~Gb}$ data per isolate. De novo assembly generated 47 and 87 contigs ( $\geq 1000 \mathrm{bp}$ ) for FADDI-PA060 and FADDI-PA107, respectively, with the corresponding total length of $6,371,158$ and 6,266,040 bp; N50 of 371,572 and 419,976 bp; and GC content of 56.9-57.3\%. In total, 5924 and 5787 genes were annotated with 5852 and 5709 coding proteins for FADDI-PA060 and FADDI-PA107, respectively.

A total of 57 genes in FADDI-PA060 and 50 genes in FADDI-PA107 were predicted to confer resistance to a variety of antimicrobials (Figures 1 and 2A). Of particular interest was the presence of 8 point mutations in each strain on genes encoding the PmrAB twocomponent regulatory system, a key system involved in the development of polymyxin resistance in P. aeruginosa [17]. A total of 15 genes in FADDI-PA060 and 13 genes in FADDIPA107 are involved with carbapenem resistance, including $b l a_{\mathrm{PDC}-8}, b l a_{\mathrm{PDC}-3}, c p x R$, mexAB, mexPQ, mexYZ, mexR, nalCD, nfxB, oprM, opmE and parRS in both isolates. The presence of genes such as mexD, oprJ, mexC, mexY, parS, mexZ, parR, oprM and cpxR, previously reported to be associated with macrolide resistance indicated the likelihood of bacterial innate resistance to this class of antibiotics [18]. Other identified genes in each strain conferred 
resistance to many antibiotic classes, including cephalosporins and fluoroquinolones. Furthermore, sox $R$ and yojC, which confer resistance to rifamycins, were identified in each strain.

(A)

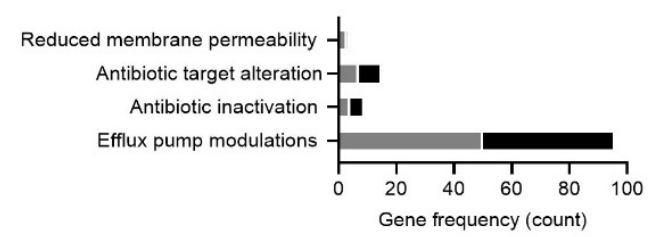

(B)

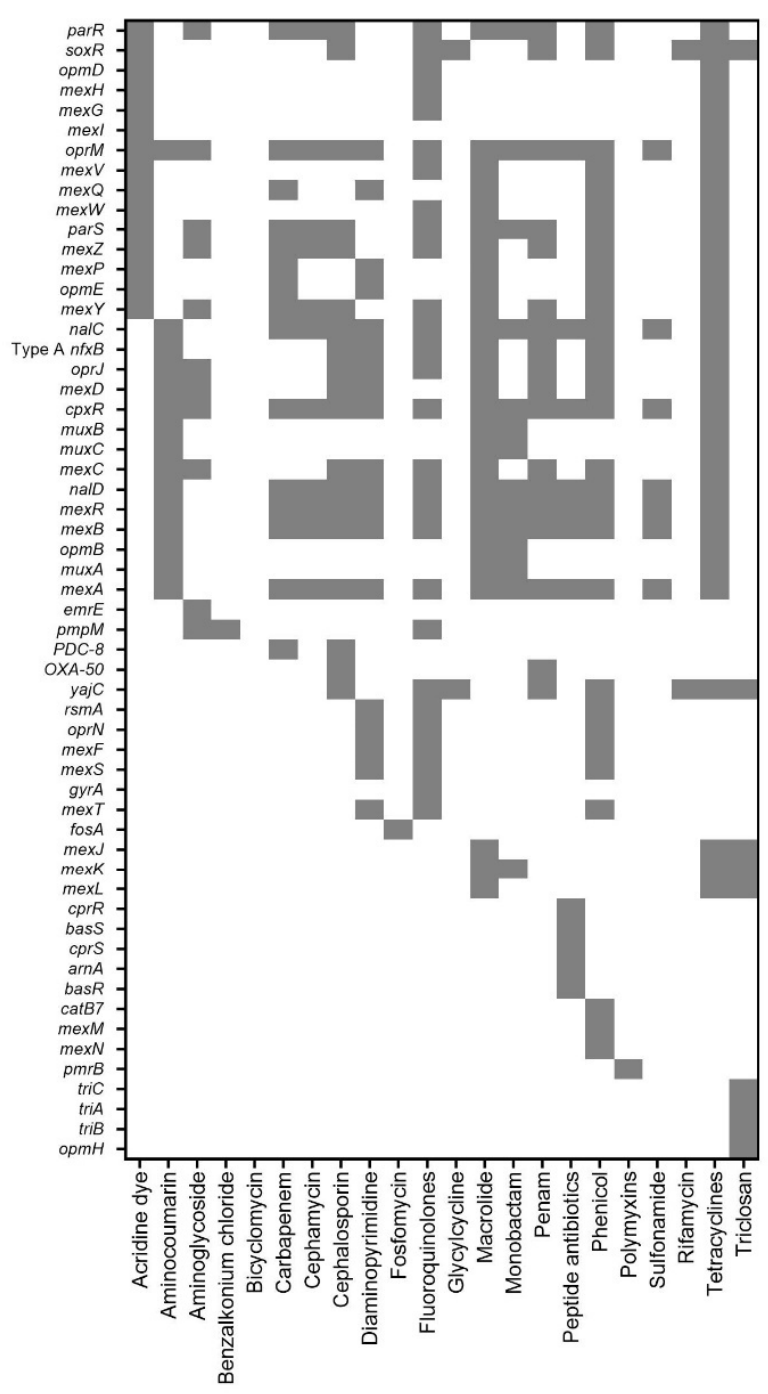

(C)

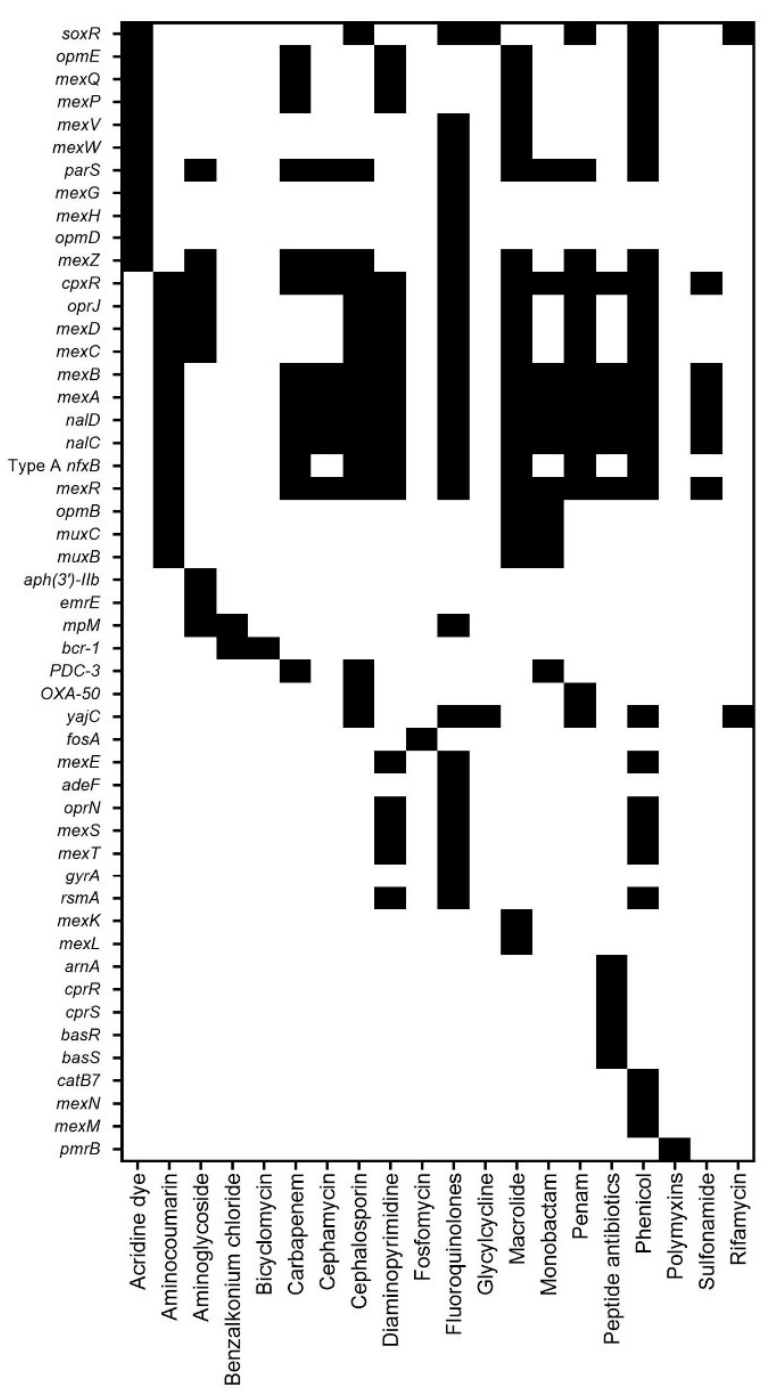

FADDI-PA060

FADDI-PA107

Figure 1. Genome-based antimicrobial resistance predictions for FADDI-PA060 and FADDI-PA107. Frequency of known antimicrobial resistance conferring functional products in FADDI-PA060 and FADDI-PA107 (A). Predicted antimicrobial resistance profiles of FADDI-PA060 (B) and FADDI-PA107 (C). The presence of a gene conferring resistance to a specific antibiotic class is marked by a shaded square. 
(A)

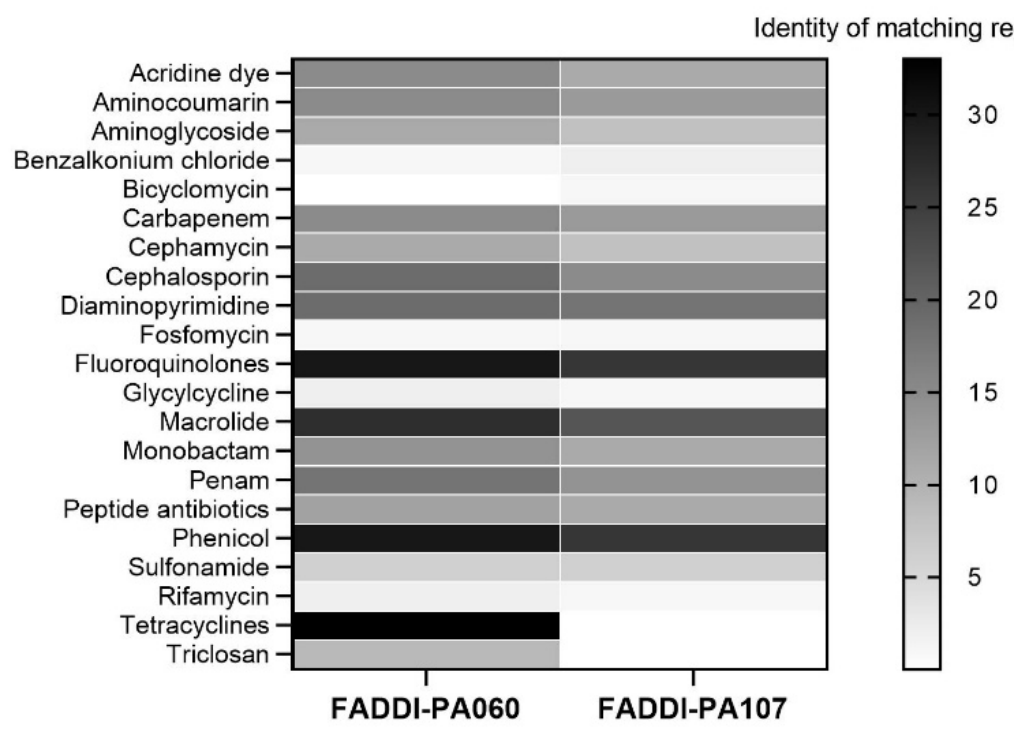

(B)

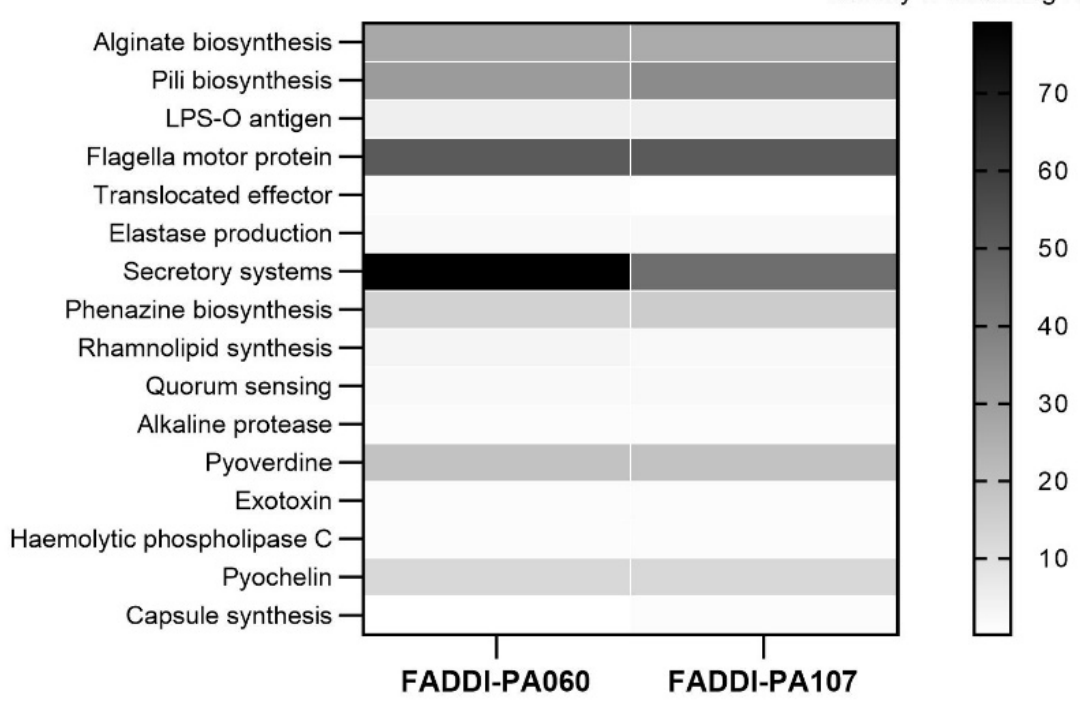

Figure 2. Abundance of genes predicted to confer resistance to different classes of antibiotics (A) and determinants of virulence factors contributing to prolonged pathogenesis $(\mathbf{B})$. The scales to the right indicate the protein sequence identity (\%) of the matching region for each determinant.

In FADDI-PA060 and FADDI-PA107, 249 and 220 putative virulence factors were identified, respectively (Figure 2B). Both strains contained genes encoding for major virulence categories including adherence (alginate and pili biosynthesis), motility (motor, flagellin and chemotaxis proteins biosynthesis), regulatory system modulators, secretion system proteins and haem-regulatory proteins. Many of these genes are genus-specific and have been previously reported to enhance pathogenesis $[19,20]$. Of particular interest are the alginate genes present in both strains which are reported to play a role in the establishment and formation of the polymeric matrix of biofilms [21]. 


\subsection{Susceptibility, Baseline Population Analysis Profiles (PAPs) and Checkerboard Assay}

The MICs of both isolates to all antibiotics studied are shown in the Table 1. As suggested by the genetic antibiotic resistance profiles (Figures 1 and 2), each isolate was MDR according to the criteria of Magiorakos et al. [22] and resistant to polymyxins. The PAPs prior to antibiotic exposure (i.e., at baseline) are shown in Figure 3. Consistent with the high polymyxin B MICs (Table 1), virtually the entire bacterial population of each isolate at this high inoculum $\left(\sim 10^{8} \mathrm{CFU} / \mathrm{mL}\right)$ grew in the presence of $16 \mathrm{mg} / \mathrm{L}$ polymyxin $\mathrm{B}$, indicating the absence of baseline sub-population heterogeneity. Results for the checkerboard assay are shown in Figure 4. Synergy was most pronounced with polymyxin B in combination with meropenem and rifampicin. Therefore, the combination of polymyxin $B$ and meropenem was chosen for further evaluation in time-kill and biofilm studies.

Table 1. Minimum inhibitory concentrations (MICs).

\begin{tabular}{ccccc}
\hline \multirow{2}{*}{ Antibacterial Agent } & \multicolumn{2}{c}{ FADDI-PA060 } & \multicolumn{2}{c}{ FADDI-PA107 } \\
\cline { 2 - 5 } & MIC $(\mathbf{m g} / \mathrm{L})$ & Interpretation & MIC (mg/L) & Interpretation \\
\hline Colistin & $>128$ & $\mathrm{R}$ & 32 & $\mathrm{R}$ \\
Polymyxin B & 64 & $\mathrm{R}$ & 32 & $\mathrm{R}$ \\
Rifampicin & 8 & $\mathrm{NA}$ & 16 & $\mathrm{NA}$ \\
Meropenem & 64 & $\mathrm{R}$ & 4 & $\mathrm{~S}$ \\
Azithromycin & 128 & $\mathrm{NA}$ & $>128$ & $\mathrm{NA}$ \\
Cefepime & $>128$ & $\mathrm{R}$ & $>128$ & $\mathrm{R}$ \\
Ciprofloxacin & 32 & $\mathrm{R}$ & $<0.125$ & $\mathrm{~S}$ \\
\hline
\end{tabular}

* The EUCAST breakpoints for colistin were applied to polymyxin B [23]. Susceptibility (S) and resistance (R) were defined as MICs $\leq 2$ and $>2 \mathrm{mg} / \mathrm{L}$ for colistin and polymyxin $\mathrm{B}$, and $\leq 2$ and $>8 \mathrm{mg} / \mathrm{L}$ for meropenem. Intermediacy and resistance were defined as MICs $\leq 8$ and $>8 \mathrm{mg} / \mathrm{L}$ for cefepime and $\leq 0.5$ and $>0.5 \mathrm{mg} / \mathrm{L}$ for ciprofloxacin [23]. Breakpoints for azithromycin and rifampicin against Gram-negative bacteria are not available (NA).

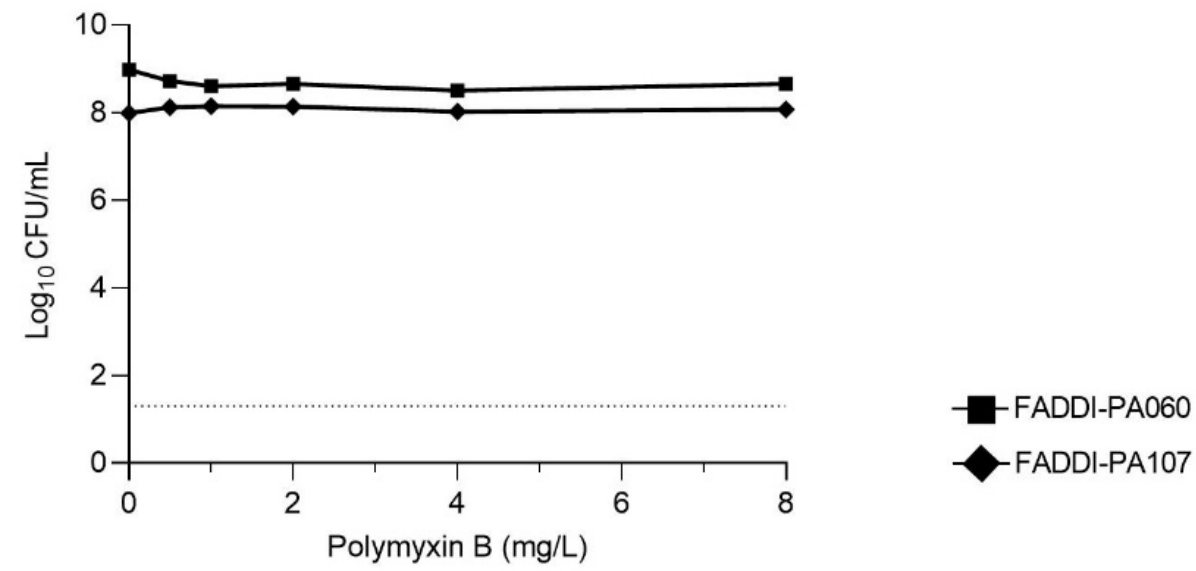

Figure 3. Baseline population analysis profiles of FADDI-PA060 and FADDI-PA107 at an initial inoculum of $\sim 10^{8} \mathrm{CFU} / \mathrm{mL}$. The limit of detection is shown by the dotted horizontal line at $1.30 \log _{10} \mathrm{CFU} / \mathrm{mL}$. 
(A) FADDI-PA060
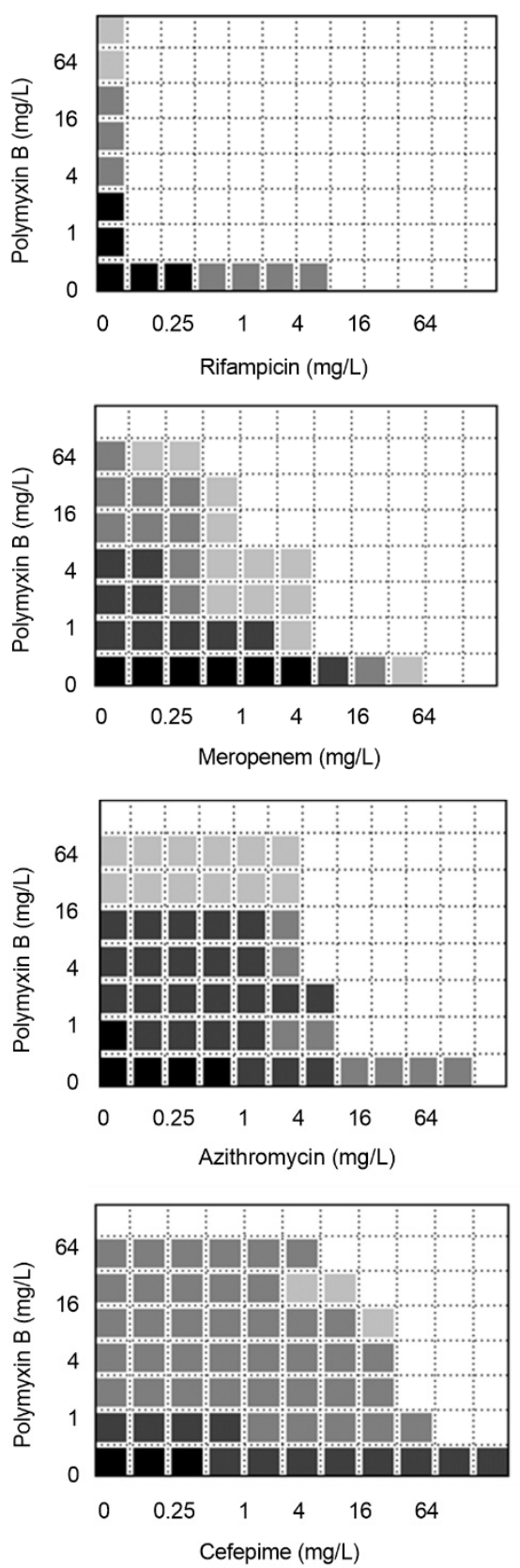

(B) FADDI-PA107
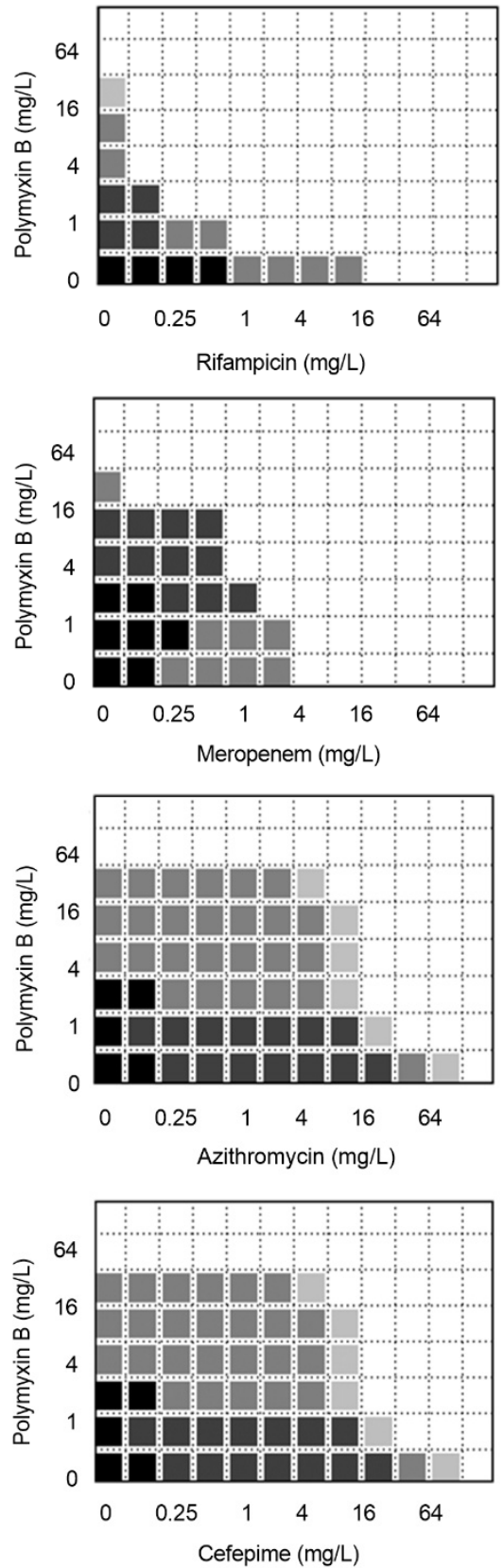

$\mathrm{OD}_{600} 0.00$ $2.00 \mathrm{AU}$

Figure 4. Checkerboard assay results of FADDI-PA060 (A) and FADDI-PA107 (B) examining polymyxin B in combination with a representative antibacterial agent from different antibacterial classes. Color gradient corresponds to the average turbidity at $\lambda=600 \mathrm{~nm}$.

\subsection{Anti-Biofilm Effects and Time-Kill Study}

Preliminary biofilm formation studies indicated substantial biofilm formation in the absence of antibiotic treatment following $24 \mathrm{~h}$ incubation (Figure S1), with no significant difference in biofilm formation following 24 or $48 \mathrm{~h}$ incubation ( $48 \mathrm{~h}$ data not shown). Biofilm formation was also reduced to varying degrees with each monotherapy and the combination (Figure S1). Based on these results, $24 \mathrm{~h}$ was selected as the preferred incubation period to analyze the initial stages of biofilm development in the dynamic model. Bacterial growth at $24 \mathrm{~h}$ in the dynamic biofilm-formation studies is shown in Figure 5. 
For FADDI-PA060, significant reductions in planktonic and biofilm growth $\left({ }^{*} p<0.05\right)$ compared to the control and monotherapy groups were only observed following exposure to the polymyxin B/meropenem combination, each at $16 \mathrm{mg} / \mathrm{L}$ (Figure 5A). FADDI-PA107 responded similarly, with no detectable planktonic or biofilm-embedded bacteria at $24 \mathrm{~h}$ with the same combination therapy (Figure 5B). Similarly, growth of planktonic bacteria above $4 \log _{10} \mathrm{CFU} / \mathrm{mL}$ and the establishment of a biofilm occurred with all other regimens against both isolates (Figure 5).

(A)

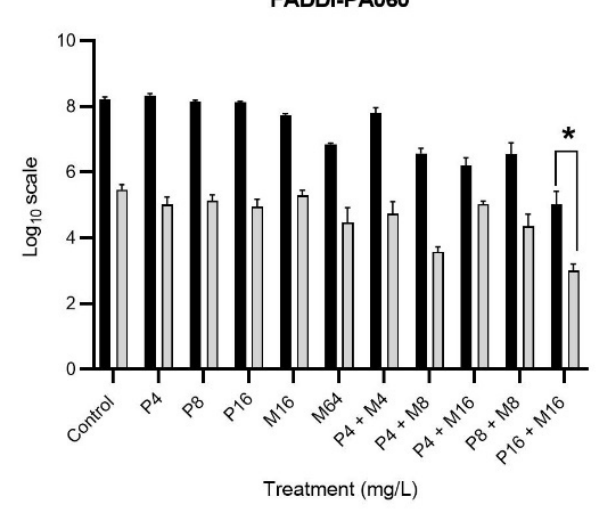

(B)

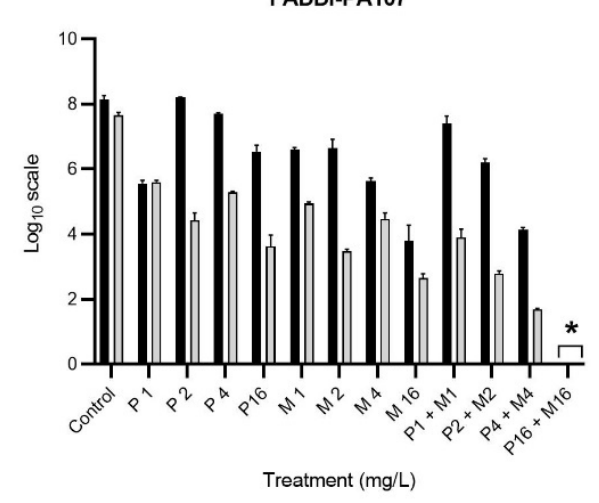

Planktonic bacteria $\left(\log _{10} \mathrm{CFU} / \mathrm{mL}\right) \quad \square$ Biofilm bacteria $\left(\log _{10} \mathrm{CFU} / \mathrm{cm}^{2}\right)$

Figure 5. Planktonic and biofilm growth of MDR P. aeruginosa; FADDI-PA060 (A) and FADDI-PA107 (B) following $24 \mathrm{~h}$ exposure to polymyxin $\mathrm{B}(\mathrm{P})$ and/or meropenem $(\mathrm{M})$ in the dynamic biofilm model. Planktonic cell counts are a measure of observed viable cell counts per $\mathrm{mL}$ whereas biofilm cell counts are a measure of observed viable cell counts per $\mathrm{cm}^{2}$ of the Teflon coupons (the aggregating surface for biofilm formation). One-way ANOVA with Kruskal-Wallis multiple comparisons versus control group * $p<0.05$. Each experiment was performed in triplicate and data are presented as mean $\pm \mathrm{SD}(n=3)$.

Based on the anti-biofilm results described above, the combination of polymyxin $B$ and meropenem (each at $16 \mathrm{mg} / \mathrm{L}$ ) was further examined in a time-kill study (Figure 6). Both monotherapies were ineffective against the meropenem-resistant isolate FADDIPA060 (meropenem MIC, $64 \mathrm{mg} / \mathrm{L}$; Figure 6A). While regrowth was observed at $24 \mathrm{~h}$, the combination had at least $3 \log _{10} \mathrm{CFU} / \mathrm{mL}$ killing within $4 \mathrm{~h}$. Against the meropenemsusceptible isolate FADDI-PA107 (meropenem MIC, $4 \mathrm{mg} / \mathrm{L}$ ), polymyxin B alone was ineffective, but rapid and substantial bacterial killing $\left(\sim 5 \log _{10} \mathrm{CFU} / \mathrm{mL}\right.$ by $\left.4 \mathrm{~h}\right)$ occurred with both meropenem monotherapy and the combination (containing meropenem at $4 \times$ MIC; Figure 6B). At 24 h, substantial regrowth (to $\sim 4 \log _{10} \mathrm{CFU} / \mathrm{mL}$ ) had occurred with meropenem monotherapy, while no viable bacteria were detected with the combination.

\subsection{Membrane Integrity Assessment}

As the proposed combination of $16 \mathrm{mg} / \mathrm{L}$ of polymyxin $\mathrm{B}$ and meropenem resulted in bacterial eradication against FADDI-PA107 in the time kill studies (Figure 6B), not enough cells from this isolate were available for further analysis. Consequently, surviving FADDIPA060 bacterial cells at $4 \mathrm{~h}$ post treatment, the time at which maximal bacterial killing was observed prior to regrowth (Figure 6A), were employed for membrane integrity studies. Treatment-induced changes to membrane polarity and permeability for FADDI-PA060 are shown in Figure 7. 
(A)

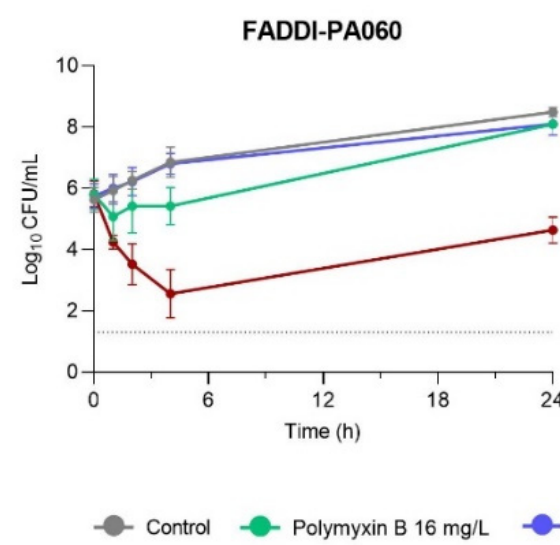

(B)

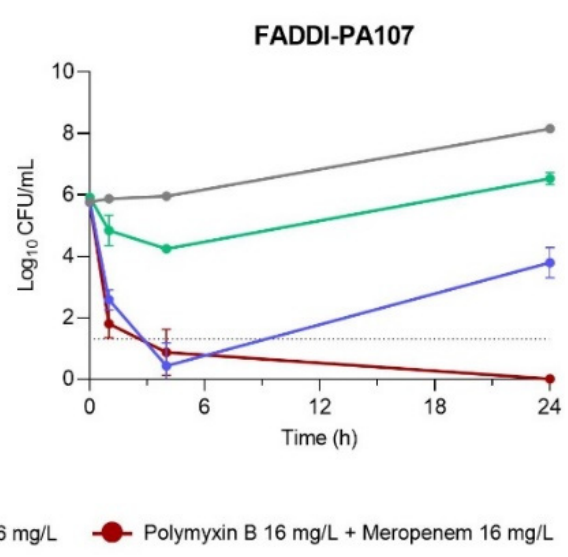

Figure 6. Time-kill curves of FADDI-PA060 (A) and FADDI-PA107 (B) with polymyxin B $16 \mathrm{mg} / \mathrm{L}$ and meropenem $16 \mathrm{mg} / \mathrm{L}$, alone and in combination, at an inoculum of $\sim 10^{6} \mathrm{CFU} / \mathrm{mL}$. The limit of detection is shown by the dotted horizontal line at $1.30 \log _{10} \mathrm{CFU} / \mathrm{mL}$. Time-kill studies were performed in triplicate and data are presented as mean $\pm \mathrm{SD}(n=3)$.

(A)

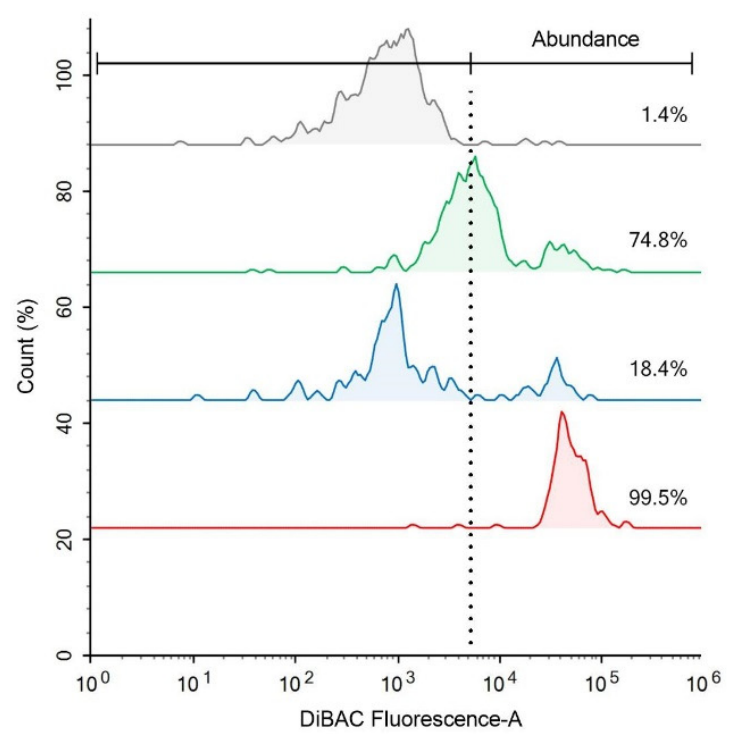

(C)

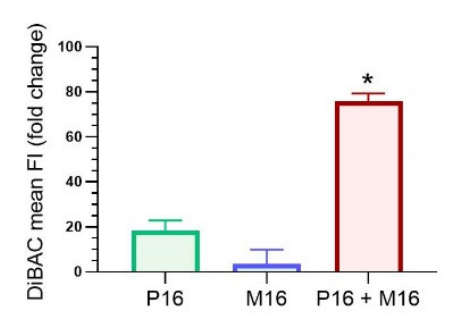

(B)

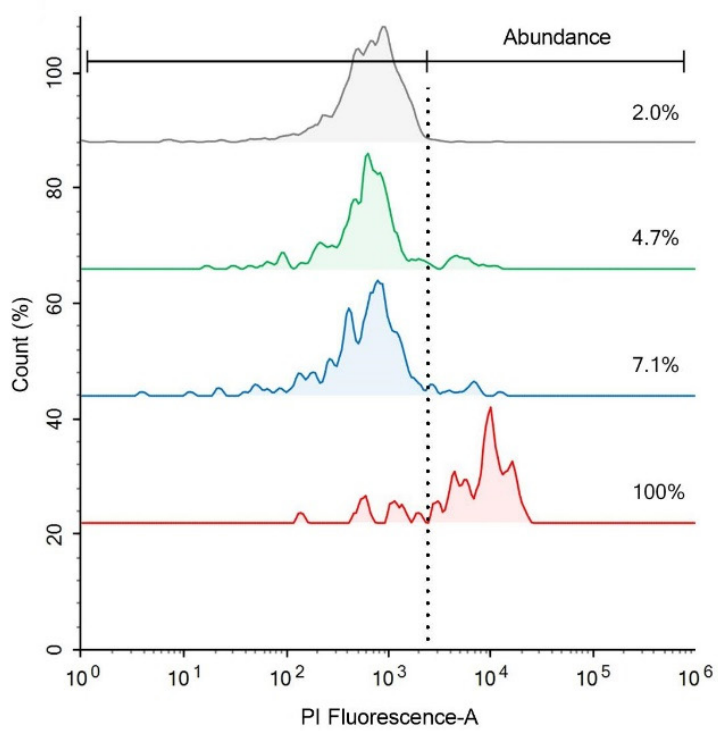

(D)

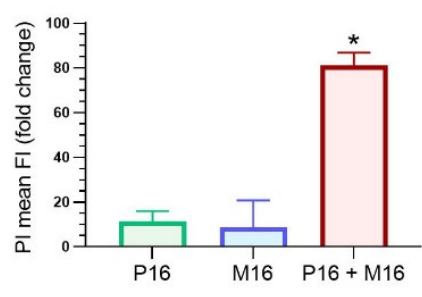

Polymyxin B $16 \mathrm{mg} / \mathrm{L}+$ Meropenem $16 \mathrm{mg} / \mathrm{L}$

Figure 7. Membrane integrity of treatment-resistant MDR P. aeruginosa FADDI-PA060 at 4 h post-exposure to polymyxin $\mathrm{B}$ and/or meropenem (each at $16 \mathrm{mg} / \mathrm{L}$ ). Treatment-driven subpopulation-based transference of DiBAC (A) and PI (B) fluorescence curves indicating the abundance of the population (\%) with increased fluorescence intensity compared to the control group (segregated with a dotted vertical line). Changes in fluorescence intensity (FI) of DiBAC (C) and PI (D) are presented as the fold change in mean fluorescence intensity normalized to the non-treated control. One-way ANOVA comparison of treatment group vs. control group $(* p<0.05)$. Data are presented as mean $\pm \operatorname{SD}(n=3)$. 
Membrane depolarization as determined by an increase in DiBAC fluorescence intensity (FI) [24], indicated that following polymyxin B monotherapy, a substantial shift in the fluorescence curve occurred with $74.8 \%$ of the population having a FI greater than that of the control group (Figure 7A,C). Within this 74.8\%, a smaller subpopulation of cells had substantially higher DiBAC FI, indicating greater membrane depolarization amongst these cells (Figure 7A). With meropenem monotherapy, $81 \%$ of the population had a membrane polarity similar to that of the control group, with the remaining $18.4 \%$ of the cells experiencing a high degree of depolarization similar to the depolarized subgroup observed with polymyxin B monotherapy (Figure 7A,C). However, following exposure to the combination therapy, $99.5 \%$ of the population experienced a high level of membrane depolarization similar to that of the subpopulations observed with each monotherapy (Figure 7A), with the mean FI significantly $\left.{ }^{*} p<0.05\right)$ higher than the control and monotherapy groups (Figure 7C). Membrane permeability as assessed by propidium iodide fluorescence [25], provided similar results to that of DiBAC. Namely, a small subpopulation of cells having increased membrane permeability with both monotherapies and, with combination therapy, movement of the entire fluorescence curve to the right with virtually all cells having significantly $\left({ }^{*} p<0.05\right)$ high PI fluorescence and therefore, substantially increased membrane permeability (Figure 7B,D).

\section{Discussion}

The discovery of antibiotics has revolutionized modern medicine [26]; however, resistance seems inevitable with almost any antibiotic and identifying novel bacterial targets has proved challenging [27]. Indeed, the WHO recently identified only 32 antibiotics in clinical development that target high-priority multidrug-resistant organisms, with only six classified as innovative (https: / / www.who.int/news-room/fact-sheets / detail/antimicrobialresistance, accessed on 7 th April 2021). Thus, there is an urgent need to optimize currently available therapeutics [26]. Given the scarcity of new antibiotics with activity against MDR Gram-negative bacteria in the antibiotic discovery pipeline, polymyxins remain a critical last-line therapy against MDR Gram-negative pathogens [11]. However, with resistance to polymyxins increasing [12], polymyxin-based combinations are frequently used in an attempt to increase antimicrobial activity and reduce resistance development, despite a lack of evidence-based treatment guidelines. It is therefore crucial that such combinations are optimized. In this study, we employed two phylogenetically unrelated clinical strains of $P$. aeruginosa, FADDI-PA060 and FADDI-PA107. FADDI-PA060 is a closely related sequence type to the DK-2 clone types found in cystic fibrosis patients over the last 35 years [28], whereas the genomic analysis reported here identified FADDI-PA107 as a newly emerging, human-related sequence type. Genomic analysis permitted the prediction of the antibacterial resistance profiles as well as virulence of the strains of interest (Figures 1 and 2), with both isolates harboring many antibiotic resistance genes (55 genes in FADDI-PA060 and 52 genes in FADDI-PA107). Genes included those encoding resistance to fluoroquinolones, macrolides, aminoglycosides, carbapenems and cephalosporins. Generally, the presence of resistance genes to a particular category of antibiotic aligned with resistance as determined by MICs, with some minor differences. Specifically, with isolate FADDI-PA107, the MICs to ciprofloxacin and meropenem were $<0.125 \mathrm{mg} / \mathrm{L}$ and $4 \mathrm{mg} / \mathrm{L}$ (both considered susceptible), respectively, despite the presence of genes conferring resistance to both antibiotics. In both cases, MICs were retested with the original MICs confirmed.

Systematic evaluation of virulence prediction genes yielded a total of 249 genes in FADDI-PA060 and 220 genes in FADDI-PA107 (Figure 2B). These genetic determinants of virulence indicated that both strains were biofilm-producing, which was subsequently confirmed in vitro. The abundance of antibiotic resistance and virulence factor-determining genes in both isolates is in agreement with the resistance to common antibiotics and prolonged disease progression observed with the DK-2 clonal types mentioned above [28-30] and suggests that FADDI-PA107 would likely cause similar problems. Having determined the resistance profiles and virulence factors of the two isolates, we undertook preliminary 
screening of polymyxin-based antibiotic combinations using multiple clinically relevant concentrations to identify potentially efficacious combinations (Figure 4). Initial screening identified meropenem and rifampicin as potential antibiotics of choice to use in combination with polymyxin B. However, rifampicin displays non-linear pharmacokinetics and has a number of toxicity issues [31], whereas the broad-spectrum bactericidal activity, wide safety margin and clinical familiarity of meropenem [32] led us to choose meropenem as the most promising candidate for clinical translatability. Subsequently, we systematically investigated the effect of polymyxin B/meropenem combinations on bacterial killing of planktonic bacteria, inhibition of biofilm formation, and membrane integrity analysis of the treatment-resistant population.

In the anti-biofilm effects and time-kill study, monotherapy with concentrations up to $16 \mathrm{mg} / \mathrm{L}$ for both polymyxin B and meropenem (and for carbapenem-resistant FADDIPA060, meropenem $64 \mathrm{mg} / \mathrm{L}$ ) were ineffective at $24 \mathrm{~h}$, with substantial regrowth present at this time even when initial killing was present (i.e., with meropenem against FADDIPA107 shown in Figure 6); biofilms were also present with all monotherapies (Figure 5). However, bacterial killing was significantly enhanced with combination therapy when each antibiotic was used at $16 \mathrm{mg} / \mathrm{L}$. Indeed, against meropenem-susceptible FADDI-PA107, this combination resulted in complete eradication of planktonic bacteria and inhibition of biofilm formation (Figure 5). While a concentration of $16 \mathrm{mg} / \mathrm{L}$ is readily achievable in both plasma and epithelial lining fluid (ELF) for meropenem (discussed below), it is unachievable in both fluids for polymyxin B if administered intravenously at currently recommended doses [15,33,34]. Unfortunately, dose-limiting nephrotoxicity precludes intravenous polymyxin dose escalation to achieve higher concentrations [8]. However, inhaled polymyxin B and colistimethate (the latter the inactive prodrug of colistin [35]) are now often used as adjunct therapy with other antibacterial agents for the treatment of respiratory tract infections such as those occurring in patients with cystic fibrosis [29,36] and ventilator-associated pneumonia [37-39]. Administration via inhalation allows for a significant amount of drug to be delivered directly into the lungs while minimizing systemic exposure [34]. Indeed, polymyxin ELF concentrations ranging from 9.53 to $1137 \mathrm{mg} / \mathrm{L}$ have been reported in patients following pulmonary administration $[15,33]$, and thus, a polymyxin B concentration of $16 \mathrm{mg} / \mathrm{L}$ is readily achievable in ELF following inhalation with standard doses.

For B-lactam antibiotics, antibacterial activity has traditionally been correlated with the fraction of the dosing interval for which the unbound concentration remains above the MIC $\left(f \mathrm{~T}_{>\mathrm{MIC}}\right)[40,41]$. For meropenem, an $f \mathrm{~T}_{>\mathrm{MIC}}$ of $\sim 40 \%$ is typically considered necessary for maximum bactericidal activity $[40,41]$, although it has recently been suggested that a value of $100 \% f \mathrm{~T}_{>4-5 x}$ MIC may be necessary to suppress resistance emergence [42]. ELF penetration of meropenem following intravenous administration of standard dosing regimens is variable, with meropenem ELF concentrations ranging from $\sim 5$ to $30 \mathrm{mg} / \mathrm{L}$ having been reported [43-45]. Thus, meropenem $16 \mathrm{mg} / \mathrm{L}$ is achievable in both plasma and ELF following intravenous administration $[43,45]$.

Although rapid polymyxin bactericidal activity and maximal killing within the first hour against polymyxin-susceptible strains has been previously observed [46,47], the polymyxin $\mathrm{B} /$ meropenem combination did not increase the rate of early killing in these polymyxin-resistant strains (FADDI-PA060 polymyxin B MIC, $64 \mathrm{mg} / \mathrm{L}$ and FADDI-PA107 polymyxin B MIC, $32 \mathrm{mg} / \mathrm{L}$ ). Based on their individual MICs (Table 1), it was no surprise that the meropenem-resistant FADDI-PA060 (meropenem MIC, $64 \mathrm{mg} / \mathrm{L}$ ) showed minimal killing of planktonic bacteria and a failure to prevent biofilm formation with polymyxin and meropenem monotherapy even at $64 \mathrm{mg} / \mathrm{L}$ (Figures 5 and 6). However, with meropenem monotherapy $(16 \mathrm{mg} / \mathrm{L})$, substantial initial killing at $4 \mathrm{~h}$ was observed against the meropenem-susceptible FADDI-PA107, followed by regrowth of planktonic bacteria and establishment of biofilm despite use of meropenem concentrations of $\sim 4 \times$ MIC (Figures 5 and 6). Sustained bacterial clearance for up to $24 \mathrm{~h}$ was only achieved with the simultaneous introduction of polymyxin B at $16 \mathrm{mg} / \mathrm{L}$. Similar initial killing followed by re- 
growth of otherwise meropenem-susceptible clinical strains of $P$. aeruginosa has previously been reported in both planktonic and biofilm-embedded bacteria exposed to meropenem monotherapy with concentrations close to or even exceeding $100 \% f \mathrm{~T}_{>\mathrm{MIC}}$ [48-50].

Formation of biofilm is a stress-induced response to environmental factors including antibiotic exposure [26,51]. In patients with indwelling medical devices and implants such as catheters, pacemakers, prosthetic devices and vascular grafts, the risk of biofilmrelated infection is high. Indeed, $\sim 60-70 \%$ of nosocomial infections are associated with implanted medical devices, with catheter-associated nosocomial infections accounting for $\sim 36 \%$ of all healthcare-associated infections [52]. In patients with cystic fibrosis, the establishment of biofilms in lungs exacerbates non-specific immune responses that mediate chronic inflammation [53]. Once established, biofilms can tolerate antibiotic concentrations up to 10-1000-times those required to kill genetically equivalent planktonic bacteria which contributes to persisting infections with low eradication success [54]. Consequently, early intervention to inhibit biofilm formation and progression greatly improves the chances of successful bacterial eradication. Therefore, inhibition of biofilm formation through the proposed polymyxin $\mathrm{B} /$ meropenem combination is important and further investigations are warranted with a range of bacterial isolates in animal pharmacokinetic/pharmacodynamic models. Given polymyxins display an inoculum effect [47] and that our anti-biofilm evaluations were based on the initial stages of biofilm formation using a starting inoculum of $\sim 10^{6} \mathrm{CFU} / \mathrm{mL}$, the effect of the proposed combination on inhibiting their formation with higher starting inocula and/or eradicating mature biofilms should also be explored.

Inclusion of the meropenem-resistant strain FADDI-PA060 allowed investigation of the response of a doubly resistant isolate to the chosen combination. Combination therapy resulted in $\sim 3 \log _{10} \mathrm{CFU} / \mathrm{mL}$ greater killing of planktonic bacteria at $4 \mathrm{~h}$ than occurred with the most effective monotherapy, with growth at $24 \mathrm{~h}$ still $\sim 4 \log _{10} \mathrm{CFU} / \mathrm{mL}$ less than the control group (Figure 6). While bacterial killing of this isolate and inhibition of biofilm formation with the combination was not as effective as against FADDI-PA107, the initial $\sim 3 \log _{10} \mathrm{CFU} / \mathrm{mL}$ greater killing observed at $4 \mathrm{~h}$ with the combination may be important in patients, given such killing may reduce bacterial numbers sufficiently for clearance by the immune system [55]. Additionally, as will be discussed below, the viable cells present at this time contained significant membrane damage, which may make the cells more amenable to further treatments (Figure 7). As the time-kill model utilized lacks an immune system, especially granulocytes that work in concert with antibiotic treatment to kill bacteria [55], future animal studies and mechanism-based mathematical models incorporating an immune system effect are warranted to fully assess the utility of this combination against isolates resistant to both antibiotics.

It is likely the different mechanisms of action and resistance of each antibiotic contributed to the enhanced bacterial killing observed with the combination. While the precise mechanism(s) by which polymyxins kill bacteria is uncertain, the initial target of polymyxins against Gram-negative bacteria is lipopolysaccharide (LPS) in the outer membrane, and the electrostatic attraction between cationic amine moieties on the polymyxin and anionic phosphate and carboxylate moieties on LPS is critical for activity [56]. Binding results in displacement of the native divalent cations and considerable outer membrane disorganization, and ultimately cell death. Membrane disruption increases membrane permeability not only to polymyxin itself but also other compounds [57]. Most identified polymyxin resistance mechanisms involve changes in LPS that negate this initial interaction [56]. While both isolates in the present study were polymyxin-resistant, membrane integrity studies involving FADDI-PA060 nevertheless showed that polymyxin B was still able to cause considerable membrane disruption (evidenced by membrane depolarization and increased membrane permeability) in most bacterial cells, with a subpopulation of cells markedly affected (Figure 7A,B). Changes associated with membrane remodeling combined with disruption of the outer membrane by polymyxin B likely improved access of meropenem to their target proteins, namely the penicillin-binding proteins located on the outside of the cytoplasmic membrane [32]. Increased intracellular meropenem concentrations by 
polymyxin B treatment (i.e., bioavailability synergy [58]) would help to negate meropenem resistance which occurs primarily due to enzymatic inactivation via carbapenemases and reduced entry into the cell via a reduction in the expression of the outer membrane porin OprD [59].

In addition to increased bioavailability of meropenem, we have previously demonstrated in colistin-susceptible Acinetobacter baumannii that colistin monotherapy causes disruption to the bacterial cell wall in addition to bacterial membranes [60]. Furthermore, doripenem alone disrupted peptidoglycan biosynthesis, whereas a combination of colistin and doripenem induced significant time-dependent changes to more key metabolic pathways relative to either monotherapy. Specifically, cell wall biosynthesis was downregulated initially by colistin (across the first hour of treatment) and later by doripenem $(4 \mathrm{~h})$. Thus, it is possible that enhanced bacterial killing in the present study may additionally result from disruption of the cell wall by both polymyxin B and meropenem. The use of such combinations also reduces the chances of the emergence of resistant mutants as separate and independent mutations are required for resistance development [61]. Interestingly, although regrowth of FADDI-PA060 nevertheless occurred following substantial initial killing, the cells at $4 \mathrm{~h}$ exhibited significant membrane depolarization and increased permeabilization thus, indicating loss of overall membrane integrity (Figure 7A,C). It is unclear if this damage is sufficient to prevent additional membrane restructuring that further reduces susceptibility to these antibiotics. The effect such damage has on these cells response to further treatment and/or immune effects should be investigated.

In summary, we identified polymyxin/meropenem as a promising combination against biofilm-producing, polymyxin-resistant MDR P. aeruginosa and systematically examined bacterial killing of planktonic bacteria, inhibition of biofilm formation and membrane integrity. Further evaluations in animal infection models will facilitate the translation into the clinic.

\section{Materials and Methods}

\subsection{Antibiotics, Bacterial Strains, Media and Susceptibility Testing}

Stock solutions of polymyxin B sulfate (Batch number 20120204; Beta Pharma Co Ltd., Shanghai, China), colistin sulfate (Batch number 20120507; Beta Pharma Co Ltd., Shanghai, China), azithromycin dihydrate (Batch number PHR1088-1G; Sigma-Aldrich, Castle Hill, NSW, Australia), cefepime (Batch number DJP-100307; Cgene Tech, Suzhou, China), ciprofloxacin (Batch number 065M4176V; Sigma-Aldrich, Castle Hill, NSW, Australia), meropenem trihydrate (Batch number MAUS1029; Fresenius Kabi, North Ryde Bc, NSW, Australia) and rifampicin (Batch number SLBK5059V; Sigma-Aldrich, Castle Hill, NSW, Australia) were used. Polymyxin B, colistin and meropenem stocks were prepared using Milli-Q water (Millipore Australia, North Ryde, New South Wales, Australia) immediately prior to each experiment and sterilized by filtration with a 0.22- $\mu \mathrm{m}$ Millex-GV PVDF filter (Millipore, Bedford, MA, USA). Meropenem stock was sonicated for 2 min prior to filter sterilization. Azithromycin, cefepime and rifampicin were dissolved in $25 \%(v / v)$ dimethyl sulfoxide (Sigma-Aldrich, Castle Hill, NSW, Australia) and 75\% (v/v) Milli-Q water, followed by filter sterilization through a 0.22- $\mu \mathrm{m}$ Millex-FG PTFE filter (Millipore, Bedford, MA, USA). Ciprofloxacin was dissolved in $0.1 \mathrm{M} \mathrm{HCl}$ (Supelco, Bellefonte, PA, USA) and filtered through a 0.22- $\mu$ m Millex-GV PVDF filter (Millipore, Bedford, MA, USA).

Two MDR strains of $P$. aeruginosa collected from patients with cystic fibrosis (FADDIPA060 and FADDI-PA107) were examined. MDR was defined as non-susceptibility to at least one agent in at least three of the following antimicrobial classes: aminoglycosides, antipseudomonal carbapenems, antipseudomonal cephalosporins, antipseudomonal fluoroquinolones, antipseudomonal penicillins plus ß-lactamase inhibitors, monobactams, phosphonic acids and polymyxins [22]. P. aeruginosa ATCC 27853 was used as the quality control strain. Strains were stored in tryptone soy broth (Oxoid, Basingstoke, Hampshire, England, UK) with $20 \%(v / v)$ glycerol at $-80^{\circ} \mathrm{C}$. Prior to each experiment, strains were subcultured onto nutrient agar (School of Biomedical Sciences Media Unit, Monash Uni- 
versity, Australia) and incubated at $37^{\circ} \mathrm{C}$ for 24 to $48 \mathrm{~h}$. Cation-adjusted Mueller-Hinton Broth (CAMHB; $\mathrm{Ca}^{2+}$ at $23 \mathrm{mg} / \mathrm{L}, \mathrm{Mg}^{2+}$ at $12.2 \mathrm{mg} / \mathrm{L}$; Oxoid, Hampshire, England, UK) was employed for all microbiological experiments.

\subsection{Genome Sequencing, Assembly and Annotation}

Bacterial log-phase cultures were used to extract genomic DNA with a DNeasy ${ }^{\circledR}$ Blood and Tissue Kit (QIAGEN, Hilden, Germany) as per the manufacturer's instructions. DNA quality and quantity were assessed using electrophoresis and Qubit (Life Technologies, Carlsbad, CA, USA) before Illumina HiSeq sequencing (paired-end 150 bp, Genewiz, Suzhou, China) [62]. De novo assembly was conducted using SPAdes [62,63] followed by annotation with NCBI Prokaryotic Genome Annotation Pipeline (PGAP). The genome sequences and annotations are available under accession number PRJNA664899. The sequence types were determined using PubMLST [64]. Antibiotic resistance genes were predicted using the Resistance Gene Identifier (RGI) 3.2.1 tool of the Comprehensive Antimicrobial Resistance Database (CARD) [18]. Putative virulence factors of FADDI-PA060 and FADDI-PA107 were predicted by blasting the whole genome against the Virulence Factor Database (VFDB) [65].

\subsection{Population Analysis Profiles (PAPs)}

Minimum inhibitory concentrations (MICs) prior to drug exposure were determined in duplicate [66]. Susceptibility and resistance were determined according to the European Committee of Antimicrobial Susceptibility Testing (EUCAST) guidelines [23].The possible existence of polymyxin-resistant subpopulations at baseline was assessed using population analysis profiles (PAPs; inoculum, $\sim 10^{8} \mathrm{CFU} / \mathrm{mL}$ ). A $50 \mu \mathrm{L}$ sample of an appropriately diluted overnight culture was manually plated on to Mueller-Hinton agar (School of Biomedical Sciences Media Unit, Monash University, Australia) containing polymyxin B at concentrations of $0,0.5,2,4$ or $16 \mathrm{mg} / \mathrm{L}$. Plates were incubated in an incubator at $37^{\circ} \mathrm{C}$ for $48 \mathrm{~h}$ and colonies counted using an automated colony counter (ProtoCOL3, Synbiosis, Cambridge, United Kingdom). The limit of detection was $20 \mathrm{CFU} / \mathrm{mL}\left(=1.3 \log _{10} \mathrm{CFU} / \mathrm{mL}\right.$, equivalent to 1 colony per plate).

\subsection{Checkerboard Studies}

An initial screen for synergy was conducted with polymyxin B in combination with rifampicin, meropenem, azithromycin and cefepime using the checkerboard microbroth dilution method [67]. These antibiotics were considered representative antibacterial agents from a variety of antibacterial classes. Following $24 \mathrm{~h}$ of incubation at $37^{\circ} \mathrm{C}$, absorbance was read using a multimode plate reader at $\lambda=600 \mathrm{~nm}$. Synergistic combinations (i.e., fractional inhibitory concentration index of $\leq 0.5$ ) were identified in order to decide which combination and concentrations would be employed in subsequent time-kill and biofilm studies.

\subsection{Biofilm-Formation and Time-Kill Study}

Based on the checkerboard study results, bacterial killing and the effect on biofilm formation of polymyxin B and meropenem were subsequently examined. An initial conditioning phase was undertaken using a previously described static biofilm model to assess the in vitro biofilm-forming capacity of each isolate [68]. A mid-log phase culture of each strain (Denville ${ }^{\circledR}$ CO8000 Cell Density Meter reading 0.5, equivalent to $\sim 10^{8} \mathrm{CFU} / \mathrm{mL}$ ) was diluted 1:100 with CAMHB to achieve a starting inoculum of $\sim 10^{6} \mathrm{CFU} / \mathrm{mL}$. Subsequently, $100 \mu \mathrm{L}$ aliquots were inoculated into a non-pyrogenic flat-bottomed microtitration plate (Thermo Scientific, Brisbane, Australia) containing $100 \mu \mathrm{L}$ of CAMHB. In order to determine the optimum conditioning phase time, one plate was initially incubated at $37^{\circ} \mathrm{C}$ for $24 \mathrm{~h}$ and a second plate for $48 \mathrm{~h}$. Following incubation, plates were washed three times with $200 \mu \mathrm{L}$ phosphate-buffered saline (PBS, pH 7.4) to remove planktonic cells and stained with $220 \mu \mathrm{L}$ of $0.1 \%(w / v)$ crystal violet solution. The stained biofilm was solubilized with $200 \mu \mathrm{L}$ of $30 \%(v / v)$ acetic acid. Absorbance (OD) was measured at $\lambda=550 \mathrm{~nm}$ using a 
multimode plate reader (Infinite M200, Tecan, Mennendorf, Switzerland) [68,69]. Results from 6 technical replicates were used to categorize each strain as a biofilm producer or non-biofilm producer using the method of Stepanovic et al. [69]. An OD value of $>2 \times$ OD of the negative control indicated biofilm production [69]. Following confirmation of biofilm formation, the inhibitory effect of antibiotic therapy on biofilm formation were examined. Polymyxin B $16 \mathrm{mg} / \mathrm{L}$ and meropenem $16 \mathrm{mg} / \mathrm{L}$ were examined as monotherapy and in combination with staining undertaken following $24 \mathrm{~h}$ of treatment at $37^{\circ} \mathrm{C}$ as described above. Changes in optical density (OD) corresponding to the change in biofilm formation were determined, and results were calculated using six replicates from two independent experiments.

To examine changes in bacterial killing and biofilm formation, time-kill studies were undertaken as described previously with minor modifications where necessary to allow for biofilm formation [70]. Briefly, a mid-log phase inoculum of each bacterial strain was diluted 1:100 in a sterile 50-mL polypropylene tube (Greiner Bio One, Kremsmunster, Austria) with CAMHB (final volume, $20 \mathrm{~mL}$ ) to establish a starting inoculum of $\sim 10^{6} \mathrm{CFU} / \mathrm{mL}$. A sterile Teflon coupon (Biosurface Technologies, Bozeman, MT, USA) was added to each $50 \mathrm{~mL}$ tube at the beginning of the experiment $(t=0 \mathrm{~h})$ for biofilm measurement. Tubes were placed in a shaking water bath (shaking speed $200 \mathrm{rpm}$ ) [71], and the experiment was conducted over $24 \mathrm{~h}$ at $37^{\circ} \mathrm{C}$. For monotherapy against FADDI-PA060, polymyxin B was added at 4,8 and $16 \mathrm{mg} / \mathrm{L}$ and meropenem at 16 and $64 \mathrm{mg} / \mathrm{L}$. For FADDI-PA107, the concentrations used were 1,2, 4 and $16 \mathrm{mg} / \mathrm{L}$ for polymyxin B and 1, 2, 4 and $16 \mathrm{mg} / \mathrm{L}$ for meropenem. Five combinations (polymyxin B $4 \mathrm{mg} / \mathrm{L}$ plus meropenem at 4,8 , or $16 \mathrm{mg} / \mathrm{L}$, polymyxin B $8 \mathrm{mg} / \mathrm{L}$ plus meropenem $8 \mathrm{mg} / \mathrm{L}$, and polymyxin B at $16 \mathrm{mg} / \mathrm{L}$ plus meropenem at $16 \mathrm{mg} / \mathrm{L}$ ) were examined against FADDI-PA060. Four combinations (polymyxin B $1 \mathrm{mg} / \mathrm{L}$ plus meropenem $1 \mathrm{mg} / \mathrm{L}$, polymyxin B $2 \mathrm{mg} / \mathrm{L}$ plus meropenem $2 \mathrm{mg} / \mathrm{L}$, polymyxin B $4 \mathrm{mg} / \mathrm{L}$ plus meropenem $4 \mathrm{mg} / \mathrm{L}$ and polymyxin B $16 \mathrm{mg} / \mathrm{L}$ plus meropenem $16 \mathrm{mg} / \mathrm{L}$ ) were examined against FADDI-PA107. Following $24 \mathrm{~h}$ of treatment, $0.5 \mathrm{~mL}$ of sample was removed for enumeration of planktonic bacteria, centrifuged at $10,000 \times g$ for $10 \mathrm{~min}$ and resuspended in sterile saline to minimize antibiotic carryover. For enumeration of biofilm-embedded bacteria, coupons were removed and biofilm-embedded cells recovered [72]. For both planktonic and biofilm-embedded cells, $50 \mu \mathrm{L}$ of undiluted or appropriately diluted sample was spirally plated onto nutrient agar plates before incubation at $37{ }^{\circ} \mathrm{C}$ for $48 \mathrm{~h}$. Colonies were counted as per PAPs and each regimen was performed in triplicate. The most effective combination was examined via an additional time-kill study on planktonic growth across $24 \mathrm{~h}(1,2,4$ and $24 \mathrm{~h})$.

\subsection{Membrane Integrity Assay}

Bacterial membrane integrity at $4 \mathrm{~h}$ post-treatment was determined using flowcytometry [25]. Samples were assessed using blue (BL) and violet (VL) laser detection channels of the ACEA NovoCyte ${ }^{\circledR}$ high-performance benchtop flow cytometer (ACEA Biosciences, Santa Clara, CA, USA). The voltage-sensitive fluorophore Bis-(1,3-Dibutylbarbituric Acid) Trimethine Oxonol (DiBAC) (Sigma-Aldrich, Castle Hill, NSW, Australia) was used as an indicator of bacterial membrane depolarization [24]. Propidium iodide (PI) (SigmaAldrich, Castle Hill, NSW, Australia), a live cell impermeant fluorophore, tagged bacterial cells with damaged cell membranes [24,25,73]. Both DiBAC (Ex/Em 488/660-690 nm) and PI (Ex/Em 488/660-690 nm) were detected in the BL-4 channel. A threshold forwardscatter (FSC-H) and side-scatter height (SSC-H) of $>1000$ units and events / s <1000 were enforced. A maximum acquisition of 20,000 events was set in the study [73]. Six hundred microliters of the appropriately diluted samples were separately stained with $1.67 \mathrm{mg} / \mathrm{L}$ DiBAC and $8.33 \mathrm{mg} / \mathrm{L}$ PI, respectively. Samples were incubated at $37{ }^{\circ} \mathrm{C}$ for $1-2 \mathrm{~min}$ and vortexed prior to analysis. The mean fluorescence intensities (FI) of DiBAC and PI correspond to the relative stain binding capacity of each cell [25]; FI data are presented as fold-changes relative to non-treated controls. 
Flow cytometry data were normalized by the mean, log transformed and analyzed using the NovoExpress ${ }^{\circledR}$ software (V 2.1 ACEA Biosciences, Santa Clara, CA, USA).

\subsection{Data Processing and Statistical Analysis}

All Experimental raw data were analyzed by one-way ANOVA using GraphPad Prism 8 (GraphPad Software Inc., San Diego, CA, USA) $(n=3)$.

Supplementary Materials: The following are available online at https:/ / www.mdpi.com/article/ 10.3390 / antibiotics10040405/s1. Figure S1: Visual representation of crystal violet staining patterns corresponding to biofilm bacterial growth following $24 \mathrm{~h}$ of either no treatment (growth controls) or treatment with polymyxin B and/or meropenem (each at $16 \mathrm{mg} / \mathrm{L})$ in the static biofilm model $(n=6)$.

Author Contributions: Conceptualization, H.W. and J.L.; methodology, H.W. and H.H.Y.; software, H.W., M.A.K.A., J.Z. and Y.Z.; validation, H.W., J.Z. and Y.Z.; formal analysis, H.W.; investigation, H.W.; resources, J.L. and Q.T.Z.; data curation, H.W.; writing—original draft preparation, H.W.; writing-review and editing, H.W., M.A.K.A., Y.Z., P.J.B. and J.L.; visualization, H.W.; supervision, J.L., Q.T.Z. and T.V.; project administration, H.H.Y.; funding acquisition, J.L. and Q.T.Z. All authors have read and agreed to the published version of the manuscript.

Funding: This research was funded by the National Institute of Allergy and Infectious Diseases of the National Institutes of Health, R01 AI132681 and R01 AI146160. J.L. is an Australian National Health and Medical Research Council (NHMRC) Principal Research Fellow.

Institutional Review Board Statement: Not applicable.

Informed Consent Statement: Not applicable.

Data Availability Statement: Data are contained within the article or supplementary material.

Conflicts of Interest: The authors declare no conflict of interest.

\section{References}

1. Livermore, D.M. Multiple Mechanisms of Antimicrobial Resistance in Pseudomonas aeruginosa: Our Worst Nightmare? Clin. Infect. Dis. 2002, 34, 634-640. [CrossRef]

2. Centers for Disease Control and Prevention. Antibiotic Resistance Threats in the United States; U.S. Department of Health and Human Services: Atlanta, GA, USA, 2019.

3. Tacconelli, E.; Carrara, E.; Savoldi, A.; Harbarth, S.; Mendelson, M.; Monnet, D.L.; Pulcini, C.; Kahlmeter, G.; Kluytmans, J.; Carmeli, Y.; et al. Discovery, research, and development of new antibiotics: The WHO priority list of antibiotic-resistant bacteria and tuberculosis. Lancet Infect. Dis. 2018, 18, 318-327. [CrossRef]

4. Theuretzbacher, U.; Gottwalt, S.; Beyer, P.; Butler, M.; Czaplewski, L.; Lienhardt, C.; Moja, L.; Paul, M.; Paulin, S.; Rex, J.H.; et al. Analysis of the clinical antibacterial and antituberculosis pipeline. Lancet Infect. Dis. 2019, 19, e40-e50. [CrossRef]

5. Behzadi, P.; Baráth, Z.; Gajdács, M. It's Not Easy Being Green: A Narrative Review on the Microbiology, Virulence and Therapeutic Prospects of Multidrug-Resistant Pseudomonas aeruginosa. Antibiotics 2021, 10, 42. [CrossRef] [PubMed]

6. Boucher, H.W.; Talbot, G.H.; Bradley, J.S.; Edwards, J.E.; Gilbert, D.; Rice, L.B.; Scheld, M.; Spellberg, B.; Bartlett, J. Bad Bugs, No Drugs: No ESKAPE! An Update from the Infectious Diseases Society of America. Clin. Infect. Dis. 2009, 48, 1-12. [CrossRef]

7. Nation, R.L.; Velkov, T.; Li, J. Colistin and Polymyxin B: Peas in a Pod, or Chalk and Cheese? Clin. Infect. Dis. 2014, 59, 88-94. [CrossRef]

8. Azad, M.A.K.; Nation, R.L.; Velkov, T.; Li, J. Mechanisms of Polymyxin-Induced Nephrotoxicity. Adv. Exp. Med. Biol. 2019, 1145, 305-319. [CrossRef] [PubMed]

9. Gales, A.C.; Castanheira, M.; Jones, R.N.; Sader, H.S. Antimicrobial resistance among Gram-negative bacilli isolated from Latin America: Results from SENTRY Antimicrobial Surveillance Program (Latin America, 2008-2010). Diagn. Microbiol. Infect. Dis. 2012, 73, 354-360. [CrossRef]

10. Jones, R.N.; Guzman-Blanco, M.; Gales, A.C.; Gallegos, B.; Castro, A.L.L.; Martino, M.D.V.; Vega, S.; Zurita, J.; Cepparulo, M.; Castanheira, M. Susceptibility rates in Latin American nations: Report from a regional resistance surveillance program (2011). Braz. J. Infect. Dis. 2013, 17, 672-681. [CrossRef]

11. Zavascki, A.P.; Goldani, L.Z.; Li, J.; Nation, R.L. Polymyxin B for the treatment of multidrug-resistant pathogens: A critical review. J. Antimicrob. Chemother. 2007, 60, 1206-1215. [CrossRef]

12. Liu, Y.-Y.; Wang, Y.; Walsh, T.R.; Yi, L.-X.; Zhang, R.; Spencer, J.; Doi, Y.; Tian, G.; Dong, B.; Huang, X.; et al. Emergence of plasmid-mediated colistin resistance mechanism MCR-1 in animals and human beings in China: A microbiological and molecular biological study. Lancet Infect. Dis. 2016, 16, 161-168. [CrossRef] 
13. Lee, W.; Cai, Y.; Lim, T.-P.; Teo, J.; Chua, S.C.; Kwa, A.L.-H. In vitro Pharmacodynamics and PK/PD in Animals. Adv. Exp. Med. Biol. 2019, 1145, 105-116. [CrossRef]

14. Bergen, P.J.; Smith, N.M.; Bedard, T.B.; Bulman, Z.P.; Cha, R.; Tsuji, B.T. Rational Combinations of Polymyxins with Other Antibiotics. Adv. Exp. Med. Biol. 2019, 1145, 251-288. [CrossRef]

15. Lin, Y.-W.; Zhou, Q.; Onufrak, N.J.; Wirth, V.; Chen, K.; Wang, J.; Forrest, A.; Chan, H.-K.; Li, J. Aerosolized Polymyxin B for Treatment of Respiratory Tract Infections: Determination of Pharmacokinetic-Pharmacodynamic Indices for Aerosolized Polymyxin B against Pseudomonas aeruginosa in a Mouse Lung Infection Model. Antimicrob. Agents Chemother. 2017, 61, e00211-e00217. [CrossRef]

16. Falagas, M.E.; Kasiakou, S.K.; Tsiodras, S.; Michalopoulos, A. The Use of Intravenous and Aerosolized Polymyxins for the Treatment of Infections in Critically Ill Patients: A Review of the Recent Literature. Clin. Med. Res. 2006, 4, 138-146. [CrossRef]

17. Moskowitz, S.M.; Brannon, M.K.; Dasgupta, N.; Pier, M.; Sgambati, N.; Miller, A.K.; Selgrade, S.E.; Miller, S.I.; Denton, M.; Conway, S.P.; et al. PmrB Mutations Promote Polymyxin Resistance of Pseudomonas aeruginosa Isolated from Colistin-Treated Cystic Fibrosis Patients. Antimicrob. Agents Chemother. 2011, 56, 1019-1030. [CrossRef]

18. Alcock, B.P.; Raphenya, A.R.; Lau, T.T.Y.; Tsang, K.K.; Bouchard, M.; Edalatmand, A.; Huynh, W.; Nguyen, A.-L.V.; Cheng, A.A.; Liu, S.; et al. CARD 2020: Antibiotic resistome surveillance with the comprehensive antibiotic resistance database. Nucleic Acids Res. 2020, 48, D517-D525. [CrossRef]

19. Bartell, J.A.; Blazier, A.S.; Yen, P.; Thøgersen, J.C.; Jelsbak, L.; Goldberg, J.B.; Papin, J.A. Reconstruction of the metabolic network of Pseudomonas aeruginosa to interrogate virulence factor synthesis. Nat. Commun. 2017, 8, 14631. [CrossRef]

20. Storey, D.G.; Ujack, E.E.; Rabin, H.R.; Mitchell, I. Pseudomonas aeruginosa lasR Transcription Correlates with the Transcription of lasA, lasB, and toxA in Chronic Lung Infections Associated with Cystic Fibrosis. Infect. Immun. 1998, 66, 2521-2528. [CrossRef] [PubMed]

21. Nivens, D.E.; Ohman, D.E.; Williams, J.; Franklin, M.J. Role of Alginate and Its O Acetylation in Formation of Pseudomonas aeruginosa Microcolonies and Biofilms. J. Bacteriol. 2001, 183, 1047-1057. [CrossRef]

22. Magiorakos, A.-P.; Srinivasan, A.; Carey, R.B.; Carmeli, Y.; Falagas, M.E.; Giske, C.G.; Harbarth, S.; Hindler, J.F.; Kahlmeter, G.; Olsson-Liljequist, B.; et al. Multidrug-resistant, extensively drug-resistant and pandrug-resistant bacteria: An international expert proposal for interim standard definitions for acquired resistance. Clin. Microbiol. Infect. 2012, 18, 268-281. [CrossRef] [PubMed]

23. The European Committee on Antimicrobial Susceptibility Testing. Breakpoint Tables for Interpretation of MICs and Zone Diameters; Version 11.0; European Committee on Antimicrobial Susceptibility Testing: Växjö, Sweden, 2021.

24. Lopez-Amoros, R.; Castel, S.; Comas-Riu, J.; Vives-Rego, J. Assessment of E. coli and Salmonella viability and starvation by confocal laser microscopy and flow cytometry using rhodamine 123, DiBAC4(3), propidium iodide, and CTC. Cytometry 1997, 29, 298-305. [CrossRef]

25. Wong, F.H.-S.; Caiet, Y.; Leck, H.; Lim, T.-P.; Teo, J.Q.-M.; Lee, W.; Koh, T.H.; Tan, T.T.; Tan, K.W.; Kwa, A.L.-H. Determining the Development of Persisters in Extensively Drug-Resistant Acinetobacter baumannii upon Exposure to Polymyxin B-Based Antibiotic Combinations Using Flow Cytometry. Antimicrob. Agents Chemother. 2020, 64, e01712-e01719. [CrossRef]

26. Walsh, T.R. A one-health approach to antimicrobial resistance. Nat. Microbiol. 2018, 3, 854-855. [CrossRef] [PubMed]

27. Hoffman, P.S. Antibacterial Discovery: 21st Century Challenges. Antibiotics 2020, 9, 213. [CrossRef]

28. Rau, M.H.; Marvig, R.L.; Ehrlich, G.D.; Molin, S.; Jelsbak, L. Deletion and acquisition of genomic content during early stage adaptation of Pseudomonas aeruginosa to a human host environment. Environ. Microbiol. 2012, 14, 2200-2211. [CrossRef]

29. Hansen, C.; Pressler, T.; Høiby, N. Early aggressive eradication therapy for intermittent Pseudomonas aeruginosa airway colonization in cystic fibrosis patients: 15 years experience. J. Cyst. Fibros. 2008, 7, 523-530. [CrossRef]

30. Burgener, E.B.; Sweere, J.M.; Bach, M.S.; Secor, P.R.; Haddock, N.; Jennings, L.K.; Marvig, R.L.; Johansen, H.K.; Rossi, E.; Cao, X.; et al. Filamentous bacteriophages are associated with chronic Pseudomonas lung infections and antibiotic resistance in cystic fibrosis. Sci. Transl. Med. 2019, 11, eaau9748. [CrossRef]

31. Combrink, M.; Loots, D.T.; du Preez, I. Metabolomics describes previously unknown toxicity mechanisms of isoniazid and rifampicin. Toxicol. Lett. 2020, 322, 104-110. [CrossRef]

32. Papp-Wallace, K.M.; Endimiani, A.; Taracila, M.A.; Bonomo, R.A. Carbapenems: Past, Present, and Future. Antimicrob. Agents Chemother. 2011, 55, 4943-4960. [CrossRef]

33. Boisson, M.; Jacobs, M.; Grégoire, N.; Gobin, P.; Marchand, S.; Couet, W.; Mimoz, O. Comparison of Intrapulmonary and Systemic Pharmacokinetics of Colistin Methanesulfonate (CMS) and Colistin after Aerosol Delivery and Intravenous Administration of CMS in Critically Ill Patients. Antimicrob. Agents Chemother. 2014, 58, 7331-7339. [CrossRef] [PubMed]

34. Yapa, S.W.S.; Li, J.; Patel, K.; Wilson, J.W.; Dooley, M.J.; George, J.; Clark, D.; Poole, S.; Williams, E.; Porter, C.J.H.; et al. Pulmonary and Systemic Pharmacokinetics of Inhaled and Intravenous Colistin Methanesulfonate in Cystic Fibrosis Patients: Targeting Advantage of Inhalational Administration. Antimicrob. Agents Chemother. 2014, 58, 2570-2579. [CrossRef] [PubMed]

35. Bergen, P.J.; Li, J.; Rayner, C.R.; Nation, R.L. Colistin Methanesulfonate Is an Inactive Prodrug of Colistin against Pseudomonas aeruginosa. Antimicrob. Agents Chemother. 2006, 50, 1953-1958. [CrossRef]

36. Jensen, T.; Pedersen, S.S.; Garne, S.; Heilmann, C.; Høiby, N.; Koch, C. Colistin inhalation therapy in cystic fibrosis patients with chronic Pseudomonas aeruginosa lung infection. J. Antimicrob. Chemother. 1987, 19, 831-838. [CrossRef] [PubMed]

37. Mubareka, S.; Rubinstein, E. Aerosolized colistin for the treatment of nosocomial pneumonia due to multidrug-resistant Gramnegative bacteria in patients without cystic fibrosis. Crit. Care 2005, 9, 29-30. [CrossRef] [PubMed] 
38. Bergen, P.J.; Bulman, Z.P.; Saju, S.; Bulitta, J.B.; Landersdorfer, C.; Forrest, A.; Cornelia, L.; Nation, R.L.; Tsuji, B.T. Polymyxin Combinations: Pharmacokinetics and Pharmacodynamics for Rationale Use. Pharmacother. J. Hum. Pharmacol. Drug Ther. 2015, 35, 34-42. [CrossRef]

39. Castellani, C.; Duff, A.J.; Bell, S.C.; Heijerman, H.G.; Munck, A.; Ratjen, F.; Sermet-Gaudelus, I.; Southern, K.W.; Barben, J.; Flume, P.A.; et al. ECFS best practice guidelines: The 2018 revision. J. Cyst. Fibros. 2018, 17, 153-178. [CrossRef]

40. Craig, W.A. State-of-the-Art Clinical Article: Pharmacokinetic/Pharmacodynamic Parameters: Rationale for Antibacterial Dosing of Mice and Men. Clin. Infect. Dis. 1998, 26, 1-10. [CrossRef] [PubMed]

41. Roberts, J.A.; Ulldemolins, M.; Roberts, M.S.; McWhinney, B.; Ungerer, J.; Paterson, D.L.; Lipman, J. Therapeutic drug monitoring of beta-lactams in critically ill patients: Proof of concept. Int. J. Antimicrob. Agents 2010, 36, 332-339. [CrossRef]

42. Roberts, J.A.; Abdul-Aziz, M.H.; Lipman, J.; Mouton, J.W.; Vinks, A.A.; Felton, T.W.; Hope, W.W.; Farkas, A.; Neely, M.N.; Schentag, J.J.; et al. Individualised antibiotic dosing for patients who are critically ill: Challenges and potential solutions. Lancet Infect. Dis. 2014, 14, 498-509. [CrossRef]

43. Frippiat, F.; Musuamba, F.T.; Seidel, L.; Albert, A.; Denooz, R.; Charlier, C.; Van Bambeke, F.; Wallemacq, P.; Descy, J.; Lambermont, B.; et al. Modelled target attainment after meropenem infusion in patients with severe nosocomial pneumonia: The PROMESSE study. J. Antimicrob. Chemother. 2014, 70, 207-216. [CrossRef] [PubMed]

44. Lodise, T.P.; Sorgel, F.; Melnick, D.; Mason, B.; Kinzig, M.; Drusano, G.L. Penetration of Meropenem into Epithelial Lining Fluid of Patients with Ventilator-Associated Pneumonia. Antimicrob. Agents Chemother. 2011, 55, 1606-1610. [CrossRef] [PubMed]

45. Wenzler, E.; Gotfried, M.H.; Loutit, J.S.; Durso, S.; Griffith, D.C.; Dudley, M.N.; Rodvold, K.A. Meropenem-RPX7009 Concentrations in Plasma, Epithelial Lining Fluid, and Alveolar Macrophages of Healthy Adult Subjects. Antimicrob. Agents Chemother. 2015, 59, 7232-7239. [CrossRef] [PubMed]

46. Bergen, P.J.; Bulitta, J.B.; Forrest, A.; Tsuji, B.T.; Li, J.; Nation, R.L. Pharmacokinetic/Pharmacodynamic Investigation of Colistin against Pseudomonas aeruginosa Using an In Vitro Model. Antimicrob. Agents Chemother. 2010, 54, 3783-3789. [CrossRef] [PubMed]

47. Tam, V.H.; Schilling, A.N.; Vo, G.; Kabbara, S.; Kwa, A.L.; Wiederhold, N.P.; Lewis, R.E. Pharmacodynamics of Polymyxin B against Pseudomonas aeruginosa. Antimicrob. Agents Chemother. 2005, 49, 3624-3630. [CrossRef]

48. Bilal, H.; Bergen, P.J.; Tait, J.R.; Wallis, S.C.; Peleg, A.Y.; Roberts, J.A.; Oliver, A.; Nation, R.L.; Landersdorfer, C.B. Clinically Relevant Epithelial Lining Fluid Concentrations of Meropenem with Ciprofloxacin Provide Synergistic Killing and Resistance Suppression of Hypermutable Pseudomonas aeruginosa in a Dynamic Biofilm Model. Antimicrob. Agents Chemother. 2020, 64. [CrossRef]

49. Carrié, C.; Petit, L.; D’Houdain, N.; Sauvage, N.; Cottenceau, V.; Lafitte, M.; Foumenteze, C.; Hisz, Q.; Menu, D.; Legeron, R.; et al. Association between augmented renal clearance, antibiotic exposure and clinical outcome in critically ill septic patients receiving high doses of $\beta$-lactams administered by continuous infusion: A prospective observational study. Int. J. Antimicrob. Agents 2018, 51, 443-449. [CrossRef]

50. Tam, V.H.; Schilling, A.N.; Neshat, S.; Poole, K.; Melnick, D.A.; Coyle, E.A. Optimization of Meropenem Minimum Concentration/MIC Ratio To Suppress In Vitro Resistance of Pseudomonas aeruginosa. Antimicrob. Agents Chemother. 2005, 49, 4920-4927. [CrossRef]

51. Zhang, L.; Dhillon, P.; Yan, H.; Farmer, S.C.; Hancock, R.E.W. Interactions of Bacterial Cationic Peptide Antibiotics with Outer and Cytoplasmic Membranes ofPseudomonas aeruginosa. Antimicrob. Agents Chemother. 2000, 44, 3317-3321. [CrossRef]

52. Bryers, J.D. Medical biofilms. Biotechnol. Bioeng. 2008, 100, 1-18. [CrossRef]

53. Langan, K.M.; Kotsimbos, T.; Peleg, A.Y. Managing Pseudomonas aeruginosa respiratory infections in cystic fibrosis. Curr. Opin. Infect. Dis. 2015, 28, 547-556. [CrossRef]

54. Jefferson, K.K. What drives bacteria to produce a biofilm? FEMS Microbiol. Lett. 2004, 236, 163-173. [CrossRef]

55. Kouyos, R.D.; Metcalf, C.J.E.; Birger, R.; Klein, E.Y.; Wiesch, P.A.Z.; Ankomah, P.; Arinaminpathy, N.; Bogich, T.L.; Bonhoeffer, S.; Brower, C.; et al. The path of least resistance: Aggressive or moderate treatment? Proc. R. Soc. B Boil. Sci. 2014, $281,20140566$. [CrossRef]

56. Moffatt, J.H.; Harper, M.; Boyce, J.D. Mechanisms of Polymyxin Resistance. Adv. Exp. Med. Biol. 2019, 1145, 55-71. [CrossRef] [PubMed]

57. Hancock, R.E.; Chapple, D.S. Peptide antibiotics. Antimicrob. Agents Chemother. 1999, 43, 1317-1323. [CrossRef] [PubMed]

58. Cokol, M.; Chua, H.N.; Tasan, M.; Mutlu, B.; Weinstein, Z.B.-E.; Suzuki, Y.; Nergiz, M.E.; Costanzo, M.; Baryshnikova, A.; Giaever, G.; et al. Systematic exploration of synergistic drug pairs. Mol. Syst. Biol. 2011, 7, 544. [CrossRef]

59. Poole, K. Pseudomonas aeruginosa: Resistance to the max. Front. Microbiol. 2011, 2, 65. [CrossRef] [PubMed]

60. Maifiah, M.H.M.; Creek, D.J.; Nation, R.L.; Forrest, A.; Tsuji, B.T.; Velkov, T.; Li, J. Untargeted metabolomics analysis reveals key pathways responsible for the synergistic killing of colistin and doripenem combination against Acinetobacter baumannii. Sci. Rep. 2017, 7, srep45527. [CrossRef]

61. Oliver, A.; Levin, B.R.; Juan, C.; Baquero, F.; Blázquez, J. Hypermutation and the Preexistence of Antibiotic-Resistant Pseudomonas aeruginosa Mutants: Implications for Susceptibility Testing and Treatment of Chronic Infections. Antimicrob. Agents Chemother. 2004, 48, 4226-4233. [CrossRef]

62. Bankevich, A.; Nurk, S.; Antipov, D.; Gurevich, A.A.; Dvorkin, M.; Kulikov, A.S.; Lesin, V.M.; Nikolenko, S.I.; Pham, S.; Prjibelski, A.D.; et al. SPAdes: A new genome assembly algorithm and its applications to single-cell sequencing. J. Comput. Biol. 2012, 19, 455-477. [CrossRef] 
63. Haft, D.H.; DiCuccio, M.; Badretdin, A.; Brover, V.; Chetvernin, V.; O’Neill, K.; Li, W.; Chitsaz, F.; Derbyshire, M.K.; Gonzales, N.R.; et al. RefSeq: An update on prokaryotic genome annotation and curation. Nucleic Acids Res. 2018, 46, D851-D860. [CrossRef] [PubMed]

64. Jolley, K.A.; Bray, J.E.; Maiden, M.C.J. Open-access bacterial population genomics: BIGSdb software, the PubMLST.org website and their applications. Wellcome Open Res. 2018, 3, 124. [CrossRef] [PubMed]

65. Liu, B.; Zheng, D.; Jin, Q.; Chen, L.; Yang, J. VFDB 2019: A comparative pathogenomic platform with an interactive web interface. Nucleic Acids Res. 2019, 47, D687-D692. [CrossRef]

66. Clinical and Laboratory Standards Institute. Performance Standards for Antimicrobial Susceptibility Testing, 30th ed.; Clinical and Laboratory Standards Institute: Wayne, PA, USA, 2020; p. 252.

67. Orhan, G.; Bayram, A.; Zer, Y.; Balci, I. Synergy Tests by E Test and Checkerboard Methods of Antimicrobial Combinations against Brucella melitensis. J. Clin. Microbiol. 2005, 43, 140-143. [CrossRef] [PubMed]

68. Merritt, J.H.; Kadouri, D.E.; O’Toole, G.A. Growing and Analyzing Static Biofilms. Curr. Protoc. Microbiol. 2011, 22, 1B.1.1-1B.1.18. [CrossRef]

69. Stepanović, S.; Vuković, D.; Hola, V.; Di Bonaventura, G.; Djukić, S.; Ćirković, I.; Ruzicka, F. Quantification of biofilm in microtiter plates: Overview of testing conditions and practical recommendations for assessment of biofilm production by staphylococci. APMIS 2007, 115, 891-899. [CrossRef]

70. Li, J.; Turnidge, J.; Milne, R.; Nation, R.L.; Coulthard, K. In Vitro Pharmacodynamic Properties of Colistin and Colistin Methanesulfonate against Pseudomonas aeruginosa Isolates from Patients with Cystic Fibrosis. Antimicrob. Agents Chemother. 2001, 45, 781-785. [CrossRef]

71. Soyer, M.; Duménil, G. Introducing Shear Stress in the Study of Bacterial Adhesion. J. Vis. Exp. 2011, 2011, e3241. [CrossRef]

72. Lora-Tamayo, J.; Murillo, O.; Bergen, P.J.; Nation, R.L.; Poudyal, A.; Luo, X.; Yu, H.Y.; Ariza, J.; Li, J. Activity of colistin combined with doripenem at clinically relevant concentrations against multidrug-resistant Pseudomonas aeruginosa in an in vitro dynamic biofilm model. J. Antimicrob. Chemother. 2014, 69, 2434-2442. [CrossRef]

73. Caron, G.N.-V.; Stephens, A.W.; Badley, R.A. Assessment of bacterial viability status by flow cytometry and single cell sorting. J. Appl. Microbiol. 1998, 84, 988-998. [CrossRef] 